\title{
The Analysis of the Connection Between the Proportion of Expenditure and Food Consumption and the Food Security of Tengger Ethnic Group's Household and the Education on Indigenous Food
}

\author{
Titi Mutiara Kiranawati, Nunung Nurjanah \\ Study Program of Tata Boga, Department of Industrial Technology \\ Universitas Negeri Malang \\ Malang Indonesia \\ titi.mutiara.ft@um.ac.id
}

\author{
Rudi Nurdiansyah \\ Study Program of Industrial Engineering \\ National Taiwan University \\ Taipei, Taiwan
}

\author{
Lismi Animatul Chisbiyah \\ Graduate Institute of Technological and Vocational \\ Education \\ National Yunlin University of Science and Technology \\ Douliu, Taiwan
}

\begin{abstract}
The purpose of this research is to analyze the food security of female household of Tengger ethnic in Ngadas village of the sub district of Poncokusumo, in the regency of Malang. This research used the method of Descriptive Analysis, which used the method of Case Study or the research that pictures a detail background and the characteristics or exclusive features from a case, especially for Tengger's female household in Malang regency.
\end{abstract}

The sample of this research is based on the approach of random sampling to the families of female in Tengger ethnic in Ngadas village, Malang regency, which was randomly chosen. The method used to collect data was interview and focus group discussion.

The result of the research shows: (1) The household characteristic is to have an average education of elementary school for the wives, while the husbands averagely have an education at the level of secondary school. The average age for the wives is 26 , while the husbands' age is 40 , (2) The average total income of the family of respondents is $R p \mathbf{5 0 0 . 0 0 0 , - ~ u n t i l ~ R p ~}$ 5 million per month. If the income is divided with the number of people inside each family, so the income per capita of the respondents is 1.5 million until 15 million each year, (3) The expenditure for food is smaller than the spending for non-food products, therefore the welfare of the respondent's family is good, (4) Based on the total expenditure, we found that the spending for food is $R p 1.052 .636$ or reach $47,46 \%$ from the total expenditure, while the non-food expenditure $R p 1.165 .283$ or
$52,54 \%,(5)$ The amount of energy consumed by the household of respondent is $1891,75 \mathrm{kkal} /$ person/day and the protein consumption is $50,4 \mathrm{gram} / \mathrm{person} / \mathrm{day}$. The amount of energy and protein consumption is comparable to $93,88 \%$ of energy sufficiency rate $93,66 \%$ of protein sufficiency rate, (6) Based on the energy sufficiency rate, the female household of Tengger ethnic is on TKG $93,88 \%$. This fact shows that they are in a normal position. Meanwhile, their protein sufficiency rate is on the position of $93.66 \%$. Therefore, we can say that it is also normal, (7) The status of food security for the female household is on the condition food security. (8) The identification of education for indigenous food for formal and informal institution.

Keywords-food security, food security for household members, females of tengger

\section{INTRODUCTION}

The government has published the governmental rule or PP number 68, 2002 about Food Security. The point is how food security is quintessential to form Indonesian society that has a good quality, independent and prosperous through the availability of food that is sufficient, safe, has a good quality, nutritious, various spread evenly in all Indonesia regions, and reachable for all people. With the government rule, food security should be an important agenda for the government along with the society. Moreover, today, many important commodities should be imported to fulfill national demands. 
Nationally sufficient food availability turns out to be unable to guarantee a regional food security, nor the food security for each village and families. Related to the fact, so the problem is how to manage the sufficient food security to be accessible for individual families on each villages.

Inside a family, women are the key actor for the achievement of food security. One of the reasons is how food security is the part of their reproductive role. The fact that a household purpose is as a consumption unit makes the reproductive role of women not only focused on the food security of their children, but the food security of the whole family. The production of food security and family's nutrition consist of a few related activities, that are the cultivation of food plants, procurement of food, the collection and reversion of food, the preparation and processing of food, and finally the distribution of food. Almost all of these activities are the assignments of women. However, the environmental and social obstacles could obstruct women to access sufficient resources to be able to do the activities of food security so that there is a fatal problem for women to do their reproductive responsibility, and often result to the bad nutritious condition of children [1].

Women have a role on production, processing, and the distribution of food in the family. Mother is the member of a family that has the most responsibility to define the kinds of food served on the table to be eaten by the whole household members. Women also have an active and important role on food security. Some research proved this, for example, the research of Quisumbing et al. [2], where they found that women play an important role to ensure food security in the family. Related to the managing of resources, many research showed that women who manage the asset or family resources are more likely spending them to buy the family's domestic needs (such as clothing, food, and so on) especially for their children, more than their husband does [3]. This means, women who have income of their own will spend their income for the family needs more than men do. Therefore, the higher the status of women's income is, the higher their possibility to achieve food security. Furthermore, the low women's status is limiting their mobility and they rarely interact with the society. Apart from that, the research of Guha-Khasnobis and Hazarika concluded that there is a positive correlation between the status of women and the food security of children, measured by their nutrition status [4].

Women play an important role to keep the food security inside their family. However, the individual data analysis on women, husbands, and children need to be analyzed in depth.

The purpose of this research is to analyze: 1) the food security of women of Tengger ethnic in Malang Regency; 2) the identification of cultural study of indigenous food on formal and informal institutions.

\section{LITERATURE REVIEW}

\section{A. Food Security}

On the World High Level Food Conference (1996), Food Security is defined as: "Food Security is achieved when everyone in every time has the access on economy, social, and physics to fulfill the daily need of food that are sufficient, safe, nutritious and various to live active and healthily". The regulation (UU) number 71996 defines Food Security as a condition when everyone inside a family always have sufficient food anytime, in terms of quantity and quality for food that is safe and economically reachable.

Food is an essential need and a part of human rights. This sentence is on the constitution of Indonesian Republic number 71996 about food that strictly stated how food is a basic need of human that the fulfilment is a human right of each Indonesian. Food fulfilment also need to available anytime. Besides, food fulfilment is not only from quantity but also quality. Food consumed need to be safe, of a good quality, and also nutritious and economically reachable.

To eat, and eat sufficiently is the basic need of everyone. Starvation is a curse for those who feel it, a disgrace for those around it, and if it is a mass starvation and happens in the middle of prosperous country, then it is a civilization defect. Ironically, until today, many people are starving. In September 2009 , at least $14.98 \%$ of people around the world are starving or undernourished. In percentage, the mortality caused by starvation only $0.7 \%$; but that means more than 7.169 .800 people, as there are 6,792 billion people around the world. Therefore, at least 13.350 people are dead because of starvation, daily.

Climate change and global financial crisis make the future of global food security blurry. Related to that issue, each countries are obliged to secure its food security. Indonesia as an agrarian country and once reached food self-sufficiency is hoped to reach and secure food security for its people.

Food security is a system consists of the sub systems of availability, distribution, and consumption. The purpose of the availability sub system is to guarantee the fulfilment of food needed by the entire society, in terms of quantity, quality variety and security. The purpose of distribution sub system is to reach an effective and efficient distribution system to guarantee that the entire families and household members can get sufficient food in terms of bot quantity and quality with a reasonable price, at any time. Meanwhile, consumption sub system has a purpose to lead people so that the national food consumption is suitable to the rule of quality, variety, nutrition, safety, and it should be hallal for Muslims. The food security in our country is still weak. This condition is proven by: a) the number of people who are in a food insecurity (consumption rate $<90 \%$ from the recommended $2.000 \mathrm{kkal} / \mathrm{kap} /$ day) and people who are highly below food security (consumption rate $<70 \%$ from the recommendation) are still very high, which are 36,85 million and 15,48 million people in 2002; (b) the number of children with malnutrition is still pretty high, which are 5,02 million and 5,12 million people in 2002 and 2003 [5]. 
According to Bustanul Arifin, food security is a high priority challenge to solve for the achievement of national prosperity in this millennium [6]. When we look on the explanation of PP 68/2002, the struggle to achieve national food security has to concentrate on local food resources that have the variety of each regions.

\section{B. Families' Food Security}

According to Indonesian constitution number 71996 about food, food security is a condition when everyone inside a family always have sufficient food anytime, in terms of quantity and quality for food that is sufficient in quantity and quality, safe, distributed evenly, and economically reachable.

Food security for household members is influenced by many factors such as the owning of physical land or field supported by a suitable climate and human resources. Farming system also influences perpetrators of production or market to provide enough food. Countries' condition with a guaranteed security not always mirror the food security of families and household members. In contrary, family's food security is an indicator of the forming of regional food security. Meanwhile, the spending for food inside a family is one of the indicators of family's food security [7]. The bigger the food spending of a family, the lower its food security. Family's food security can also be seen from nourishment indicator. The indicator is macronutrients or protein and energy. From the research of Purwaningsih [8], concluded that the food security of North Sulawesi is guaranteed, but there are still a vast number of families with food insecurity. The expenditure proportion for people with food insecurity in villages are relatively higher than those in the cities. Generally, the source of income for people with food insecurity is dominant on the farming sector. The amount of the average expenditure proportion of food compared to the entire spending is $60 \%$, which means the expenditure for food is still the majority of farmers' family's expenditures. Rosyadi and Purnomo in their research stated that the share or proportion in the family's expenditure for food needed is much higher than the expenditure for non-food needs, which is averagely $78 \%$ for food, while $22 \%$ is for the non-food needs [9].

Therefore, a district achieve food security when there is an increase on food production, effective food distribution, and food consumption that is safe and nutritious for the whole society [10]. Food security consists of 3 sub system, which are: 1) Food Availability 2) Food Access 3) Food Utilization [11].

On poor families, the expenditure for food will be much bigger than the non-food expenditure so that it will influence the nutrition fulfilment on the determination of family's food security. Nutrition fulfilment gained from consumed food are going to determine the consumption rate. The higher the nourishing rate of a food in term of the consumed energy, the higher the energy consumption rate will be. It is also applied to protein consumption. A village cannot be said to be independent if it still has food security problems reflected with no increase of income and prosperity [8].

\section{Family's Expenditure Pattern}

The percentage of expenditure for food will decrease when the income increases. Therefore, the composition of family's expenditure could be an indicator for people's prosperity. The lower the percentage for food in total expenditure, the better people economics rate is. Keynes's consumption theory on his book The General Theory of Employment, Interest and Money explains the connection between the disposable income and the immediate consumption. In other words, income that someone has in a time will influence the consumption in that time. When the income is increasing, then the consumption will also increase, and vice versa [12]. The difference of income rate will result to the difference of income distribution pattern, including the pattern of family consumption. In a limited condition or a low income, someone will prioritize the fulfilment for food before other needs and spend the income on food. The lower the expenditure for income is, that means people's prosperity is getting better [13].

\section{Food Consumption Pattern}

In Indonesia, the most consumed energy resource is rice, and the other one is cassava [14]. The main difference of food consumption is located in the consumption rate of villagers and townies. The result of National Socioeconomic Survey (SUSENAS) in 2011 showed that the rice consumption in villages is much higher than the consumption in towns and cities. In the family level, the development of food consumption rate is also reflecting the rate of income or family's purchasing power. The increase of income will make individuals tend to increase the quality of their food consumption by buying expensive foods. When there is an increase in income, the food consumption pattern will be more various so that the consumption of a better nutritious food will also increase [14]. The rate of nourishment can be used as an indicator to show the rate of population prosperity measured by the amount of calories and protein consumed.

A good eating pattern should include staple foods, side dishes, fruits and vegetables that are eaten in a sufficient amount, suitable with what we need. A good eating pattern and a various dish can guarantee the fulfilment of power source, so the nutritious state will be better and strengthening the immunity system [15].

\section{E. Food Nutrition}

The standard of sufficient calorie and protein consumption per capita per day according to WNPG 2012 is $2150 \mathrm{kkal}$ and 57 gram. The fulfilment of food needs is indicated from the fulfilment of energy and protein [11]. The other nutrition's will be fulfilled if the consumption of energy and protein is enough suitable to the Amount of Nutrition Sufficiency (Angka Kecukupan Gizi / AKG). One's ANS will be different to the others according to their age and gender. Meanwhile, Rate of Energy Consumption (Tingkat Konsumsi Energi / TKE) is gained through comparing protein or energy consumption with the recommended AKG. The consumption of protein and energy of the family is gained from the measure of nutritious value of the consumed foods, from the Family Rate (Ukuran Rumah Tangga / URT) or from the Edible Part (Bagian makanan yang Dapat Dimakan / BDD). The analysis of 
nutritious value could use The List of Food Compositions (Daftar Komposisi Bahan Makanan / DKBM) that consists of the composition of energy, protein, fats, carbs, and so on. DKBM is from the Nutrition Directors of the Health Department of Indonesian Republic as a standard. The classification of consumption is divided into 4 , which are:

- Good $: \mathrm{TKG} \geq 100 \% \mathrm{AKG}$

- Intermediate : TKG 80-99\% AKG

- Minus : TKG 70-80\% AKG

- Deficit $:$ TKG $<70 \%$ AKG

\section{F. Tengger Ethnic}

Tengger is an ethnic located around Mount Bromo. The population live around the district of Pasuruan, Probolinggo, and Malang. The closest ethnic to the Tengger is the Javanese ethnic, but there are some cultural differences between the two ethnics. Kurniasudar stated that [16]:

The width of Tengger territory is more or less $40 \mathrm{KM}$ from North to South, and 20 - $30 \mathrm{KM}$ from East to West, and the height is around $1000 \mathrm{M}-3675 \mathrm{M}$ above the sea level. The Caldera of Tengger is a wide desert located on the height of 2300M, with the length of 5-10 KM. The Crater of Mount Bromo is on the height of $2392 \mathrm{M}$, and it is still active. On the South, there is the peak of Mount Semeru in the height 3676M above the sea level. The geographic location like this has a great influence in forming the culture of Tengger ethnic.

One of the villages lived by the Tenggers is in Ngadas village, Poncokusumo, Malang Regency. Ngadas is one of the 36 villages of Tengger that are spread into four regencies. Located in the middle Bromo Tengger Semeru National Park (BTSNP), Ngadas is the enclave of BTSNP, and the weather is airly cold in the height of at least $2200 \mathrm{mdpl}$, with the average temperature of $0^{\circ} \mathrm{C}-20^{\circ} \mathrm{C}$. The width of the area is around 395 with the hills topography, and most of the people are farmers, with 50\% Javanese Buddhist, Muslims 40\%, and Hindis $10 \%$.

Ngadas is a village in Poncokusumo district, Malang Regency, East Java Province. Ngadas is one of the 36 villages of Tengger ethnic that are spread into four regencies, which are Probolinggo, Lumajang, Pasuruan and Malang.

\section{G. Cultural Education of Indigenous Food}

East Java Province has a famous tourism asset of Bromo Tengger Semeru National Park (BTSNP). This is an important asset, and it has the Kasoso cultural ceremony. On each ceremonies, there are various special foods. Apart from the ceremonious foods, Tengger has many unique daily foods that are unknown to the world. The foods could be developed to be a supporting tourism in the form of eco-tourism on the aspect of ethnic culinary.

The act and perception of the usage of the National Parks in Indonesia is the influence of cognitive interpretation. A study in Bromo Tengger Semeru National Park (BTSNP) pictured that the allocation of time in East Asia regions need a stronger contextualization, alternatives, and a better market realization that the economic benefit and the conservation from the tourism will be maximized [17]. As the local cultural wisdom in the means of ethnic foods needs to be conserved.

\section{RESEARCH METHOD}

This research used the method of Descriptive Analysis, which used the method of Case Study or the research that pictures a detail background and the characteristics or exclusive features from a case, especially for Tengger's female household in Malang regency.

The sample of this research is based on the approach of random sampling to the families of female in Tengger ethnic in Ngadas village, Malang regency, which was randomly chosen.

The method used to collect data was interview and focus group discussion. The survey officers are given a training about the key concepts related to the survey, including the definition of the female family in Tengger. To determine whether the identified people are home-based workers or not, the survey officer asked a few questions related to the respondents' occupation to verify their status as the Tenggers before they begin the interview. The main instrument used for the research is the questionnaire. The focus group discussion was also being held to get a better understanding about the family's food security.

To answer the purpose of the variety on food security for the female family of the Tengger ethnic, the characteristics of food security are used and combined to the food security characteristic using AKE and PPP and served into 4 quadrants [18]. From the data, we can find out the distribution of the variation on food security for the female family in the Tengger ethnic, Malang Regency. The variety of food security then will be served in the groups of food secure, food insecure, lack of food, and deficit of food in the form of percentage.

The female family of Tengger will gain independence of food if what they consume could be fulfilled by their own production, showed by the value of KP(i) equal 1 . The bigger the value of KP is, then the farmer family condition is going to be more independent in term of food. The smaller the value of $\mathrm{KP}$ is (less than 1), then the farmer family is on the condition of the lack of food.

The Analysis of Income and Expenditure of Farmer Family is gained by the questionnaire. The income of farmers' family is divided into two, which are the primary family income and the secondary family income. The expenditure of the family is analyzed with the analysis of percentage and the average number.

\section{DISCUSSION}

\section{A. The Characteristics of Respondents' Family}

The Characteristics of Respondents' Family including the data of respondents' and their family identity. The data also include the age, education level, and the number of the respondent's household members. The characteristics of the respondents' family is served on the Table 1. 
TABLE I. THE CHARACTERISTICS OF THE FEMALE FAMILY OF TENGGER ETHNIC ON MALANG REGENCY

\begin{tabular}{|l|l|l|}
\hline No. & \multicolumn{1}{|c|}{ Description } & Average \\
\hline \multirow{3}{*}{1} & Age (year) & \\
\cline { 2 - 3 } & Husband & 40 \\
\cline { 2 - 3 } & Wife & 36 \\
\hline 2 & Education Level & \\
\cline { 2 - 3 } & Husband & Secondary \\
\cline { 2 - 3 } 3 & Wife the & 3 \\
\hline \multirow{2}{*}{3} & $\begin{array}{l}\text { Number of } \\
\text { Household Member }\end{array}$ \\
\hline
\end{tabular}

Based on the Table 1, it is known that the average age of the husbands are 40 years old and the wives 36 years old. Therefore, the average age is 38 years old. That age is still included on the productive group of age, so it means that they can still do their work maximally, so they can have enough income to fulfill their family's daily needs.

The average education level of the wives is on the elementary level. This means that the level of wives' education is still low, while the husbands' level of education is averagely on secondary school. The education and knowledge of the housewives is influencing the family's food consumption. Housewives are the decision maker for food consumption as generally, they are the ones who deal with the problems in the kitchen and prepare the food for the whole household members. The number of the household member is averagely three. The number of household member is influential to the need of food for the family. The more the number is, the more they would need food. Apart from that, it also influences the amount of income in the family, the more household members who work, the greater their income will be.

\section{B. The Income per Capita for the Family of Tengger Ethnic}

The family income of the women in Tengger is divided into 2 , which are the primary and secondary income. In the $2^{\text {nd }}$ Table, the average income of the respondents can be seen. In this research, the income is measured from the primary and secondary income of the family. The primary income is from the head of the family, and the secondary is from the other family members.

The average total income of the respondent is between Rp. 500.000 to $\mathrm{Rp} 5$ million per month. If the total income is divided with the number of family members, then we can get the value of the income per capita, which is between $\mathrm{Rp} .1 .5$ million to 15 million per year.

The average income gained from farming is sufficient for their needs of food. This is in accordance to the finding of Suprihatin that in the villages or rural areas, there are plenty of husbands and wives that work hard as the needs of the family are increasing [19].

\section{The Women's Family Expenditure}

Family expenditure is the cost spent for the consumption of the entire household members. The family expenditure is grouped into 2, which are the food and non-food expenditure.

The share of food expenditure in the total expenditures of the Tenggers is $69.5 \%$. Family expenditure is the cost spent for the consumption of the entire household members. The family expenditure is grouped into 2 , which are the food and non-food expenditure. The average family expenditure per month for food is Rp 1.052.636 and the non-food expenditure is $\mathrm{Rp}$ 1.165.283, so the average family expenditure is $\mathrm{Rp} 2.217 .919$.

The biggest expenditure is for rice and other grains, which is $29.50 \%$. The second biggest is for fish, eggs, milk and meats for about $26.50 \%$. The expenditure for drinking materials such as sugar, coffee and tea is $10.97 \%$. The expenditure for spices is $2.24 \%$. The expenditure for vegetables $4.75 \%$. The other consumptions are $6.47 \%$ of the food expenditure. The expenditure for any kinds of nuts is $6.09 \%$. The expenditure for oil and fats is $4.07 \%$. The expenditure for fruits $3.73 \%$, and for tubers (cassava and such) is $2.6 \%$.

The biggest expenditure for non-food is for things and service, which is $53.37 \%$. The next is social needs with $15.58 \%$ and clothing with $8.21 \%$ including clothes, shoes, hats, and so on. For taxes and insurance, the amount is $2.84 \%$. Health bills is only $2.65 \%$, while the long lasting things take up $1.65 \%$ including the furniture, kitchen sets, entertainments, and so on. Meanwhile, the gap between the income and expenditure is for savings.

Based on the explanation above, we know that the expenditure for food is smaller than the non-food one. Based on the data, we can conclude that the prosperity rate of the respondents' family are good. The lower their expenditure for food is, the more prosper they are.

\section{The Proportion of Food Consumption Expenditure and the Total Family Expenditure of the Respondents}

Food consumption expenditure is a percentage of the amount of food expenditure compared to the amount of total expenditure. Here is the proportion of respondents' family expenditure. The amount of the total average expenditure on the research is $\mathrm{Rp}$ 2.217.919. Based on the total expenditure, we know that the amount spent for food is $\mathrm{Rp} 1.052 .636$ or $47.46 \%$ of the total expenditure. Meanwhile, the non-food expenditure is $\operatorname{Rp} 1.165 .283$ or $52.54 \%$.

\section{E. Respondents' Consumption of Energy and Protein}

Energy and protein consumption can be used to measure food quantity. The average consumption of energy and the nutrition value is explained on the Table 2 .

TABLE II. THE AVERAGE ENERGY AND PROTEIN CONSUMPTION AND THE RATE OF FAMILY'S NOURISHMENT

\begin{tabular}{|l|l|l|l|}
\hline \multicolumn{1}{|c|}{ Nutritious Value } & Average & $\begin{array}{c}\text { Recommended } \\
\text { AKG }\end{array}$ & TKG(\%) \\
\hline $\begin{array}{l}\text { Energy } \\
\text { (kkal/person/day) }\end{array}$ & 1891,75 & $2.015,17$ & $93,88 \%$ \\
\hline $\begin{array}{l}\text { Protein } \\
\text { (gram/person/day) }\end{array}$ & 50,4 & 53,81 & $93,66 \%$ \\
\hline
\end{tabular}


Based on the Table 2, we know that the average amount of energy consumption in the family is $1891.75 \mathrm{kkal} /$ person/day and protein consumption is $50.4 \mathrm{gram} /$ person/day. The amount of energy and protein consumption is comparable to $93.88 \%$ of energy value rate and $93.66 \%$ of protein value rate. The spread of energy and protein value is divided into 5 groups, which are highly deficit ( $<70 \% \mathrm{AKG})$, intermediately deficit (70-79\% AKG), lightly deficit (80-89\% AKG), normal (90-119\% AKG) and over $(\geq 120 \% \mathrm{AKG})$.

Based on the rate of family's energy sufficiency for the women of Tengger ethnic that is in AKG 93.88\%, it shows that they are in the normal position. Meanwhile, the protein sufficiency is on $93.66 \%$. Therefore, it is also normal. Energy and protein is two components of nutrients that are important for living things. Energy is to fuel of living things' activities, while protein has a role on growth and development, and to keep the body networks.

\section{F. Family's Food Security}

The proportion of food expenditure and energy consumption is the components to determine family's food security. Family's food security can be classified as: food secure, food insecure, lack of food, and deficit of food. Based on the data, we know that the status of family's food security for the women's family of Tengger ethnic is on the condition of Food Secure.

\section{G. Identification on Cultural Education of Indigenous Food}

Formally, the cultural education on the indigenous food of Tengger is not the part of the material given to the elementary school students in Ngadas village, as the research location. However, it is only a part of informal internalization on each families there.

\section{CONCLUSION}

- The characteristics of the respondents' family are the average education level of elementary school for the wives and secondary school for husbands. For the age, it is averagely 26 years for wives and 40 years for husbands.

- The average total income gained by the respondents is between Rp. 500,000 to Rp 5 million per month. If the total income is divided with the number of household members, then the income per capita is between Rp. $1,500,000$ to $15,000,000$ each year.

- Food expenditure is smaller than the non-food one, so it means that the prosperity rate of the respondents' family is good.

- Based on the total expenditure, we know that the amount spent for food is $\mathrm{Rp} 1.052 .636$ or $47.46 \%$ of the total expenditure. Meanwhile, the non-food expenditure is $\operatorname{Rp} 1.165 .283$ or $52.54 \%$.

- The average amount of energy consumption in the family is $1891.75 \mathrm{kkal} / \mathrm{person} /$ day and protein consumption is $50.4 \mathrm{gram} /$ person/day. The amount of energy and protein consumption is comparable to
$93.88 \%$ of energy value rate and $93.66 \%$ of protein value rate.

- Based on the rate of family's energy sufficiency for the women of Tengger ethnic that is in AKG 93.88\%, it shows that they are in the normal position. Meanwhile, the protein sufficiency is on $93.66 \%$. Therefore, it is also normal.

- The status of family's food security for the women's family of Tengger ethnic is on the condition of Food Secure.

- The indigenous food of Tengger ethnic is not on the formal and non-formal cultural education yet.

\section{REFERENCES}

[1] APRODEV, "EPAs - What's in it for women," A gender based impact assessment study on "WOMEN IN ZIMBABWE: ISSUES IN FUTURE TRADE NEGOTIATIONS WITH THE EU,” 2002. [Online]. Available: http://trade.ec.europa.eu/doclib/html/122300.htm. [Accessed: 21-May2016].

[2] A. R. Quisumbing, L. R. Brown, H. S. Feldstein, L. Haddad, and C. Peña, "Women: The key to food security," Food policy statement, vol. 21, 1995.

[3] A. R. Quisumbing and J. A. Maluccio, "Resources at marriage and intrahousehold allocation: Evidence from Bangladesh, Ethiopia, Indonesia, and South Africa," Oxf. Bull. Econ. Stat., vol. 65, no. 3, pp. 283-327, 2003.

[4] B. Guha-Khasnobis and G. Hazarika, "Women's status and children's food security in Pakistan," Food Secur., vol. 95, 2006.

[5] A. Khomsan, Pangan dan gizi untuk kesehatan. Jakarta: PT. Raja Grafindo Persada, 2003.

[6] B. Arifin, Pembangunan pertanian: paradigma kebijakan dan strategi revitalisasi. Jakarta: Grasindo, 2005.

[7] A. Pakpahan, H. P. Saliem, and S. H. Suhartini, Penelitian tentang ketahanan pangan masyarakat berpendapatan rendah, 14th ed. Pusat Penelitian Sosial Ekonomi Pertanian, Badan Penelitian dan Pengembangan Pertanian, 1993.

[8] Y. Purwaningsih, "Ketahanan Pangan: Situasi, Permasalahan, Kebijakan, dan Pemberdayaan Masyarakat," J. Ekon. Pembang. Kaji. Masal. Ekon. dan Pembang., vol. 9, no. 1, pp. 1-27, 2008.

[9] I. Rosyadi and D. Purnomo, "Tingkat Ketahanan Pangan Rumah Tanggga di Desa tertinggal," J. Ekon. Pembang., vol. 13, no. 2, pp. 303315, 2012.

[10] E. Rahmawati, “Aspek Distribusi pada Ketahanan Pangan Masyarakat di Kabupaten Tapin," J. Agribisnis Pedesaan, vol. 2, no. 3, pp. 241-251, 2012.

[11] M. Adriani and B. Wirjatmadi, Pengantar Gizi Masyarakat. Jakarta: Kencana, 2012.

[12] C. Pujoharso, "Aplikasi teori konsumsi keynes terhadap pola konsumsi makanan masyarakat Indonesia," J. Ilm. Mhs. FEB, vol. 1, no. 2, 2012.

[13] M. Ariani, E. Ariningsih, I. Kariyasa, and M. Maulana, Kinerja dan Prospek Pemberdayaan Rumah Tangga Rawan Pangan dalam Era Desentralisasi. Jakarta: Departemen Pertanian, 2007.

[14] A. Yudaningrum, "Analisis Hubungan Proporsi Pengeluaran dan Konsumsi Pangan Dengan Ketahanan Pangan Rumah Tangga Petani di Kabupaten Kulon Progo,” Universitas Sebelas Maret, 2011.

[15] Y. F. Baliwati, A. Khomsan, and C. M. Dwiriani, Pengantar pangan dan gizi. Jakarta: Penebar Swadaya, 2004.

[16] K. S. Putra, "Suku Tengger," 2013. [Online]. Available: https://kurniasudiar.wordpress.com/2013/05/06/suku-Tengger/. [Accessed: 14-Jun-2017].

[17] J. Cochrane, Asian tourism: Growth and change. Routledge, 2007.

[18] S. Maxwell and M. Smith, Household food security: a conceptual review. Rome and New York: IFAD and UNICEF, 1992. 
[19] S. Suprihatin, "Alokasi waktu keluarga di pedesaan dan desa kota kasus di Dua Desa Kecamatan Ciomas Kabupaten Bogor, Jawa Barat,” Institut
Pertanian Bogor, 1986. 